\title{
ETIKA ILMIAH ISLAM SEBAGAI WUJUD TOLERANSI (Analisis Pemikiran Taha Jabir al-Alwani dalam Kitab Adab al-Ikhtilafi fi al Islami)
}

\author{
M. Ulil Abshor \& Husnul Khotimah \\ Fakultas Ushuluddin dan Humniora UIN Antasari Banjarmasin \\ ulilabshor91@gmail.com/husnulkhatimah@uin-antasari.ac.id \\ Diterima 06-03-2020 | Direview 02-04-2020 | Diterbitkan 27-06-2020
}

\begin{abstract}
:
The rise of change and the behavior of society today change the distortion or differences in factors, news and issues those are freely scattered in the mass media are no longer heard by the Indonesian people, so it becomes the people's consumption that is swallowed raw so that it starts to fix it. When people take news and information about and direct then many questions arise, it is appropriate, but the problem is all the news that comes from the mass media used to criticize and disbelieve others, this causes a variety of differences that result in the decline of humans to be able to support each other and make a difference as a mercy for all nature. All kinds of actions that cause conflict and friction between human beings are triggered by negative ideological reasoning that challenges its truth. Because reason and ideology that are formed do not show a more wise view and behavior in responding to differences. Therefore, the author wants to discuss more deeply about ethical knowledge and scientific knowledge of scientific ethics capable of realizing a tolerant attitude and understanding perspective. Of course this author uses the Content Analysis method as the main reference in examining the views of Taha Jabir al-Alwani about attitudes and actions relating to science using interpretive-descriptive methods. Then the results obtained from scientific ethics are resolved (1). Self-awareness consists of magical, naive, critical and transformative awareness, (2). Social awareness consists of mutual support, compilation, understanding, (3). Revolution awareness and (4). Divine Awareness is a difficult challenge to avoid because of hostility, strife, strife, termination of akin relations which is opposed by Allah.
\end{abstract}

Keywords: Scientific Ethics, Islamic Reason and Tolerance

\begin{abstract}
Abtrak:
Maraknya sikap dan perilaku masyarakat dewasa ini mengalami distorsi entah disebabkan beragam faktor, berita dan isu yang bebas bertebaran di media massa sudah tak asing lagi didengar oleh masyarakat Indonesia, sehingga menjadi konsumsi publik yang ditelan
\end{abstract}


mentah mentah hingga kemudian diyakini kebenarannya. Ketika masyarakat menjadikan berita dan informasi sebagai acuan dan pedoman yang kemudian banyak menimbulkan banyak perbedaan, hal itu sangatlah wajar, namun yang menjadi masalah adalah segala berita yang bersumber dari media massa digunakan untuk menyalahkan dan mengkafirkan orang lain, ini menjadi sebab timbulnya beragam konflik yang memicu terpuruknya perilaku manusia untuk bisa saling menghargai dan menjadikan perbedaan sebagai rahmat bagi seluruh alam. Segala macam tindakan yang menyebabkan konflik dan gesekan antar umat manusia dipicu oleh nalar ideologi negatif yang diyakini kebenarannya. Karena nalar dan ideologi yang terbentuk tidak menunjukkan pandangan dan perilaku yang lebih bijak dalam menyikapi perbedaan. Oleh karena itu, penulis ingin menggali lebih dalam lagi pentingnya pengetahuan etika ilmiah dan bagaimanakah nalar etika ilmiah Islam mampu mewujudkan sikap toleran dan menghargai perbedaan pendapat. Tentu hal ini penulis menggunakan metode Content Analisis sebagai rujukan utama dalam menelaah pandangan Taha Jabir al-Alwani mengenai sikap dan tindakan yang secara ilmiah dengan menggunakan metode deskriptif interpretatif. Maka hasil yang diperoleh dari etika ilmiah mencakup (1). Kesadaran diri berupa magis, naif, kritis dan transformatif, (2). Kesadaran sosial berupa saling menghargai, memahami, memaklumi, (3). Kesadaran revolusioner, dan (4). Kesadaran Ilahi berupa betapa pentingnya menghindari perbuatan permusuhan, perselisihan, percekcokan, pemutusan hubungan kerabat yang dilarang oleh Allah Swt.

Kata Kunci: Etika Ilmiah, Nalar Islam dan Toleransi

\section{Pendahuluan}

Manusia diciptakan oleh Allah Swt diberi akal untuk difungsikan sebagaimana mestinya, dengan akal inilah manusia mampu membedakan perbuatan baik dan buruk, perbuatan baik buruk ini disebut dengan moral. ${ }^{1}$ Bahwa etika dalam khazanah pemikiran Islam biasa dimasukkan dalam apa yang disebut sebagai filsafat praktis (albikmah al-amaliyah). Orientasi filsafat yang mengarah pada bentuk perilaku berdasarkan sumber al-Qur'an dan asSunnah.

\footnotetext{
${ }^{1}$ Haidir Putra Daulay, Endidikan Islam Dalam Sistem Pendidikan Nasional Di Indonesia (Jakarta:
} Kencana, 2012). 
Persoalan moral tetap menjadi sebuah diskursus yang menarik untuk dikaji secara filosofis terutama pada zaman pra Islam dan Islam. Hal itu disebabkan tidak adanya sebuah sistem peraturan moral dalam diri manusia telah menimbulkan kerusakan (destruktivitas) moral di dalam suatu masyarakat. ${ }^{2}$ Sedangkan etika merupakan sebuah ilmu yang menjelaskan mengenai baik buruk, etika lebih condong ke arah teori. Sementara moralitas itu perilaku praksisnya yang nampak diri manusia. ${ }^{3}$

Memperbicangkan moral dan etika tentu perlu tahu kondisi umat Islam saat ini dari pelbagai aspek kehidupan telah mengalami kemunduran moralitas, kelemahan intelektual, kemiskinan dan boros, tanpa adanya keadilan dan kesepakatan yang sama. Oleh karena itu, bencana paling berbahaya yang menimpa umat Islam saat ini karena basis kurangnya pemahaman tentang tata moral praksis dalam memahami perbedaan pendapat hingga perselisihan yang tak kunjung usai direlai. Sehingga etika yang bersifat ilmiah menjadi tumpuan utama dalam memberi pemahaman yang lebih harmonis, humanis dan aktual. Hal ini prioritas utama yang ditekankan untuk memperoleh persatuan dan kesatuan antar hubungan sesama manusia. Agar mereka saling menghargai dan memiliki nalar toleransi yang mewujud dalam perilaku sehari sehari semakin dibutuhkan hingga terinternalisasi dalam wujud sikap praksis dan teoritis. ${ }^{4}$ Sehingga pluralitas dan keragaman berfikir tak menghalangi tindakan seseorang dalam memahami sebuah etika tersebut.

Keragaman berfikir yang dimaksud oleh penulis sering kali memicu tindakan kekerasan, subjektifitas penilaian dan kepentingan diri sendiri yang didorong oleh motivasi egoistik masing masing individu berkembang dan tumbuh makin lama makin besar, merasuk jauh ke dalam dunia mental seseorang lalu merantai buah pikiran, perilaku dan perasaan. Gejala ini memberi pengaruh pada setiap individu karena dipenuhi oleh kefanatikan pemahaman. Kefanatikan pemahaman akan melahirkan cacatnya pemahaman terhadap makna dari pedoman dan aturan etika yang sebenarnya telah ditentukan oleh Agama Islam itu sendiri. ${ }^{5}$

Mengenai artikel yang menjadi penelusuran penulis adalah etika. Etika dalam pandangan Alwani disebut sebagai Adab, sehingga basis pemahaman

\footnotetext{
2 Ahmad Charis Zubair, Kuliab Etika (Jakarta: Rajawali Press, 1967).

${ }^{3}$ Ahmad Amin, Ethika Ilmu Akblaq (Jakarta: PT Bulan Bintang, 1988).

${ }^{4}$ Taha Jabir Fayyad Al-Alwani, Adab Al-Ikbtilaf Fi al-Islam (USA: Islamic Thought, 1987).

${ }^{5}$ Taha Jabir Fayyad Al-Alwani.
} 
tentang etika tidak selesai dalam konteks "Text" itu ditulis dalam sebuah buku. Namun, etika yang dimaksud disini merupakan sebagai tindakan praksis yang membawa para pelaku mampu menyadari betapa pentingnya akal sehat mendorong persepsinya untuk menjadi tumpuan dalam bertindak, berfikir dan bersikap. Akal dalam hemat penulis kemampuan mendayagunakan nalar yang mampu mengontrol, memelihara dan mempelajari tindakan untuk lebih cakap ketika berhadapan dengan persoalan yang menimbulkan perpecahan dan perselisihan di masyarakat. ${ }^{6}$

Bertebaran informasi dan pengetahuan baik di jejaring sosial atau issu issu yang gak kredibel muatannya akan memberikan pengaruh kepada manusia untuk bertindak secara spontanitas, tindakan spontanitas ini menjadi bagian dari wawasan yang direngkuh seiring dengan massifnya arus informasi yang tak terbendung oleh akal pikiran manusia, sehingga perlu adanya filterisasi pengetahuan, filterisasi pengetahuan dibutuhkan sebagai alternatif dalam bingkai normatif untuk mewujudkan tindakan selektif dan preventif. Hal ini dilakukan agar mampu bersikap secara lebih toleran, menghargai dan menghindarkan dirinya dari suasana sikap yang saling memperselisihkan dan memperdebatkan pendapat secara tidak sehat. Oleh karena itu, sumbangan terbesar terhadap pentingnya perubahan dalam hidup secara praksis adalah mengenai pentingnya mengetahui, memahami, menyelami, menggumuli, menyadari etika dalam beda pendapat menjadi bagian pokok dari tulisan artikel ini, penulis mencoba menelusuri perihal etika ilmiah dari karya Taha Jabir alAlwani dengan judul versi Inggris "The Ethics of Disagreement in Islam" versi Arabic "Adab al-Ikbtilaf fi al-Islami" yang mampu memberi sumbangan dalam mewujudkan nalar toleransi dan saling menghargai, memahami dalam situasi berbeda pendapat.

Kajian ini penting dibahas lebih lanjut, mengingat semakin banyaknya problem perpecahan umat dan perselisihan disebabkan perbedaan pendapat atas hal yang diketahui dan dipahami, padahal pengetahuan dan wawasan menjadi suatu hal yang wajar, namum penyikapan yang menimbulkan berceraiberai pertemanan menjadi bagian yang pokok, sehingga dengan latar belakang tersebut bagaimanakah Alwani memetakan terkait peran etika ilmiah Islam dalam mewujudkan nalar toleransi dalam kaitannya beda pendapat? Lalu apa sumbangan yang dilakukan oleh Alwani dalam menjadikan etika sebagai hal pokok dalam pemikirannya?

\footnotetext{
${ }^{6}$ Taha Jabir Fayyad Al-Alwani.
} 


\section{Metode}

Penelitian ini dilakukan dengan menggunakan content analysis (analisis isi) terhadap dokumen tertulis yang mengungkap dasar dasar tentang etika ilmiah menurut Taha Jabir al-Alwani dalam karya "The Ethics of Disagreement" nilai dasar etika merupakan landasan tingkah laku seseorang mengenai wadah wujud toleransi, wadah tersebut yang memungkinkan menemui peristiwa dan kejadian yang menimpa dirinya, utamanya dalam kaitanya bergaul dengen seseorang dalam berbeda bahasa, budaya, mazhab, pemikiran, ideologi dan tentunya Agama. Analisis isi (content analysis) ialah metode yang digunakan untuk mengkaji isi pemikiran, baik pemikiran yang berupa ideologi, bahasa dan mazhab. Teknik mengambil kesimpulan melalui analisis isi dilakukan dengan mengidentifikasi berbagai karakteristik khusus (tak semua dicantumkan) suatu pesan secara objektif dan sistematis. Dalam memahami dan mendialogkan argumen tersebut, penelitian ini juga menggunakan pendekatan tematik, artinya metode yang digunakan dalam menginterpretasikan teks tersebut dengan menghimpun dan menganalisis sejumlah teks-teks yang terkait dengan tema kajian utamanya dalam bidang kajian etika. Dengan demikian, penelitian ini bersifat kualitatif yang menitikberatkan pada kajian pustaka (library research) dan akan menghasilkan data deskriptif.

\section{Biografi Dr. Taha Jabir Al-Alwani}

Biografi Dr. Taha Jabir Al-Alwani dilahirkan di Iraq 1354 H/1935 M.

Dia memperoleh pendidikan dasar dan menengahnya di tanah kelahirannya sendiri, kemudian mendapatkan gelar B.A dari Fakultas Syari'ah dan Hukum di Universitas al-Azhar Kaior pada tahun 1378 H/1959 M. Di universitas yang sama pula gelar master dan doktoralnya dalam bidang Ushul Fiqih masing masing pada tahun 1968 M \& 1973 M. Selepas sarjana al-Awani kembali ke Iraq dan menjadi anggota Letnan pasukan militer di Iraq dan mengajar di Akademi militer Iraq di Baghdad, sekaligus mengajarkan ilmunya di perguruan Tinggi dalam bidang Islamic Studies di mana dia menjadi Guru Besar selama 6 tahun. Selama 10 tahun dia menjadi guru besar dalam bidang fiqih dan Ushul Fiqib di Universitas Muhammad Ibn Sa'ud di Riyadh Mekkah. Al-Alwani kemudian memutuskan untuk hijrah ke USA pada tahun 1983 M, dia menetap di Northern Virgina selama 23 tahun. Sekaligus dia juga membidani dalam pendirian "The International Institute of Islamic Thought" di USA pada tahun 
1401H/1981 M dan saat ini menjabat presiden pada sejumlah lembaga yang dipimpinya sebagai dewan komisaris di antaranya pendiri sejumlah lembaga. ${ }^{7}$

Al-Awani menulis dan menerbitkan karya-karyanya lebih dari 30 buah buku tentang beragam issu issu Islam termasuk terkait tentang "etika beda pendapat". Dia menggagas banyak pemikiran baru tentang perubahan dan gagasan-gagasan yang kemudian melahirkan tren baru dalam bidang kajian Islamic Studies. Ia menulis tentang Islamisasi pengetahuan, kewajiban untuk berjihad dan sumbangan fiqih aqalliyat (hukum minoritas fiqih) yang berhubungan dengan persoalan pandangan orang Islam di Negara di mana mereka yang minoritas dan intinya lebih spesial dan luar biasa menguasai kondisi kondisi tersebut. Al-Awani dikenal pula dalam karyanya sebagai Qur'anic Interpreters (penafsir al-Qur'an). Bukunya yang berjudul 'Tadabbur' dia membahas bagaimana memahami al-Qur'an dengan menggunakan al-Qur'an itu sendiri sebagai cara yang berbeda dengan para mufassir al-Qur'an. Karena al-Awani menyakini keragaman latar belakang dan pendidikan mufassir membawa bias dan perbedaan di antara orang Islam dalam menafsirkan alQur'an. ${ }^{8}$

Pada suatu ketika ia sempat menangis, kebingungan, hatinya menyempit disebabkan pertanyaan-pertanyaan yang baru itu tak ditemukan jawabannya dalam kitab-kitab induk di atas. Sampai pada akhirnya ia membaca Al-Qur'an, merenungi, memikirkan prinsip-prinsi universalnya yang berikutnya nanti akan menjadi apa yang ia sebut sebagai al-Maqaid al-'ulya hakimah."

\section{Pemikiran Tentang Etika Ilmiah}

Etika atau Ethics berasal dari Yunani yaitu Ethos yang artinya kebiasaan. Karena membicarakan kebiasaan atau perbuatan, namun bukan membicarakan tentang tata-adat akan tetapi yang dibahas adalah tata-adab yang berdasarkan inti sifat dasar manusia. jadi bisa dipastikan bahwa etika merupakan teori tentang perbuatan manusia yang ditimbang menurut baik buruknya ${ }^{10}$ Etika

\footnotetext{
${ }^{7}$ Taha Jabir Fayyad Al-Alwani, The Ethics of Disagreement in Islam, vol. 1 (USA: Herndon, 1993).

8 Taha Jabir Fayyad Al-Alwani.

${ }^{9}$ Alwani Zainab, Muraja'at Fi Tatawnur al-Manhaj al-Maqashidiy 'Inda al-Mu'Ashirin (al-Ma'had al'Alamiy li al-Fikr al-Islami, n.d.).

${ }^{10}$ Achmad Mudlor, Etika Dalam Islam (Surabaya: Al-Ikhlas, 1988).
} 
menjadi salah satu hal yang sangat krusial dan pokok dalam hidup dan bersosial, karena mengandung nilai-nilai dan moralitas yang bersifat normatif dan cenderung praksis. ${ }^{11}$ Etika dalam konteks praksis merupakan sebuah karakter bagaimana seharusnya menjadi manusia yang beretika dan bermoral kesadaran- diri karena dengan memiliki kesadaran bermoral tentu segala aspek tindakan dan perilakuanya bernilai etis. Sedangkan etika dalam konteks refleksi merupakan sebuah pemikiran tentang etika yang diketahui secara tindakan baik dan buruk, boleh dan tidak boleh, etis dan tidak etis. ${ }^{12}$

Etika ilmiah penting untuk menjadi acuan dalam kajian praksis. Karena etika ini menyoroti berbagai macam kemunduran moralitas, kelumpuhan intelektual, perubahan dari dalam diri, kepengaruhan dari luar, hilangnya keadilan dan kesamaan hak, pemerasan dan korupsi, sangat tak peduli, kemiskinan dan boros, ketergantungan dan ketidaknyamanan, perselisihan dan sikap penolakan, dengan persoalan daftar panjang dan menyakitkan. ${ }^{13}$ Etika dan moral dua hal yang perlu dibedakan secara jelas, supaya menjadi struktur pemikiran analisis yang jelas di antara kedua hal, karena etika bisa jadi menjadi perilaku yang bersifat baik jika dilihat secara aspek moral. Kali ini penulis mengurai sedikit hal bahwa etika bagi $\mathrm{K}$. Bertens ialah "etika" berasal dari bahasa Yunani kuno, yang berarti ethos dalam bentuk mempunyai banyak arti: tempat tinggal yang biasa, padang rumput, kandang, adat istiadat, akblak, watak, perasaan, sikap dan cara berpikir. Sedangkan, kata "moral" berasal dari bahasa latin mos (jamak: mores) yang memiliki arti kebiasaan. ${ }^{14}$

Kata etika dan moral biasanya diartikan sebagai suatu kebiasaan atau adat istiadat (custom atau mores). Akan tetapi, pada perkembangan selanjutnya kata "ethic" berubah artinya menjadi sebuah bidang kajian filsafat atau ilmu pengetahuan tentang moral atau moralitas. Berdasarkan pernyataan itulah moralitas menunjuk kepada perilaku atau perbuatan manusia. Dengan demikian, maka istilah etika bisa dipahami sebagai suatu penyelidikan atau

\footnotetext{
${ }^{11}$ Magnis Suseno, Franz, Filsafat Sebagai Ilmu Kritis (Yogyakarta: Kanisius, 1992).

${ }^{12}$ Magnis Suseno, Franz.

${ }^{13}$ Taha Jabir Fayyad Al-Alwani, The Ethics of Disagreement in Islam, 1993.

${ }^{14}$ K. Bertens, Etika (Jakarta: Gramedia, 2006).
} 
kajian secara sistematis tentang perilaku bisa juga disebut teori yang berhubungan dengan perilku atau moralitas.

Dalam konteks ini, Lorens Bagus mendefinisikan moralitas ${ }^{15}$ adalah sebagai tekad manusia dalam mengikuti keinginan yang terdapat di dalam hati seseorang, hal ini disebutnya sebagai kewajiban mutlak. Sehingga moralitas dipahaminya sebagai kualitas dalam perbuatan manusia yang menunjukkan bahwa tindakan itu berkaitan dengan benar atau salah, baik atau buruk, jahat dan jelek. Dengan demikian, moralitas mencakup pengertian tentang baikburuknya perbuatan manusia. ${ }^{16}$ Jadi hal yang dapat dinilai baik dan buruk berasal dari sikap manusia yang menyangkut perbuatan, tindakan, tingkah laku, gerakan kata kata dan sebagainya. Adapun motif atau watak suara hati, nurani sulit untuk dinilai secara positivistik. Ruang lingkup etika meliputi bagaimana caranya agar dapat hidup lebih baik dan mengetahui caranya berperilaku baik serta mampu menghindari perilaku yang buruk. ${ }^{17}$ Etika memang pada dasarnya memerlukan sikap kritis, metodis dan sistematis dalam upaya melakukan refleksi. Inilah yang kemudian etika menjadi kajian ilmu teoritis tentang perilaku baik dan buruknya manusia.

Tujuan dalam mempelajari dan memahami etika tidak lain hanyalah ingin memperoleh konsep yang sama mengenal penilaian baik dan buruk bagi semua manusia dalam ruang dan waktu tertentu. Etika menjadi sebuah keilmuwan yang normatif karena menyangkut sikap dan tingkah laku manusia berkait dengan baik dan buruk. Sedangkan konsep ilmiah di sini yang penulis maksud bersifat ilmu, artinya secara ilmu pengetahuan memenuhi syarat-syarat dan kaidah yang berlaku bagi perkembangan ilmu pengetahuan dewasa ini. Dalam kamus ilmiah populer kata ilmiah berarti bersifat keilmuan atau sains yang memberi beragam aturan sistematis dan metodis. ${ }^{18}$ Hal tersebut bisa ditarik kesimpulan bahwa etika ilmiah merupakan sebuah karakter logis yang bersifat ilmiah sehingga menjadi landasan berfikir teoritis dan kemudian

\footnotetext{
${ }^{15}$ Magnis Suseno, Franz, Filsafat Sebagai Ilmu Kritis.

16 W Poespoprodjo, Filsafat Moral; Kesusilaan Dalam Teori Dan Praktek (Bandung: Pustaka Grafika, 1999).

${ }^{17}$ Sudarsono, Ilmu Filsafat, 2nd ed. (Jakarta: Rineka Cipta, 2008).

18 A Partanto Pius, Kamus Ilmiah Populer (Surabaya: Arkaloka, 1994).
} 
melahirkan perilaku yang sesuai dengan syarat syarat kaidah tertentu, dan metode di dalam ilmu pengetahuan secara sistematis.

Sebelum penulis bergerak lebih jauh dalam kaitannya membahas tentang etika. Perlu digaris bawahi adalah etika yang penulis kaji di sini bersifat khusus. Sebab kajian tentang etika ada dua bentuk, etika secara umum dan etika secara khusus. Etika umum yang mengkaji suatu pemikiran kritis dan mendasar tentang ajaran ajaran dan pandangan pandangan moral dari perlbagai aliran. Sementara kajian etika secara khusus mengkaji bagaimana seorang harus bertindak dalam bidang atau masalah tertentu, dan bidang tersebut perlu ditata, dikelola agar mampu menunjang kebahagiaan hidup manusia yang lebih baik lagi. ${ }^{19}$

\section{a. Etika Ilmiah Islam Taha Jabir al-Alwani}

Allah Swt menciptakan manusia di dunia ini pada dasarnya diberi potensi berupa akal, kehendak nafs dan hati. Ketiga potensi tersebut secara tidak langsung mengundang potensi berbeda dalam tataran praksis dengan manusia yang lain. Karena hal ini sudah termasuk suatu keniscayaan wujud asma wa sifatnya Allab yakni Laisa Kamitslibi Syaiun tidak ada satupun yang menyamainya bentuk rupa-Nya. Pada dasarnya potensi manusia mendorong untuk memunculkan permasalahan yang berbeda baik dari segi ucapan, pemikiran, ideologi, mazhab, gagasan, pengalaman dan bahkan konsep imajinasi. Permasalahan yang menimbulkan perbedaan pendapat kalau dalam Islam disebut dengan Ikhtilaf (Beda pendapat). Berbeda pendapat atau beda pendapat merupakan salah satu anugerah Tuhan dan termasuk tanda-tanda kebesaran Allah Swt. Sesuai dalam al-Qur'an (QS. Hud : 118-119).

"Sesunggubnya segala kemakmuran yang ada di jagat raya ini termasuk tegaknya kehidupan tidak akan tervujud bila manusia diciptakan dalam keadaan yang sama dalam segala bal, mulai dari proses penciptaan sampai pada metode berpikir hasil ciptaan Allab itu."

Perlu ditekankan di sini perihal konsep beda pendapat dalam pandangan Taha Jabir al-Alwani. Ia membedakan antara Ikbtilaf, Jadal dan Syiqaq. Ikbtilaf secara terminologi merupakan cara mengambil sikap atau posisi

${ }^{19}$ Magnis Suseno, Franz, Kuasa Dan Moral (Jakarta: Gramedia, 1988). 
berbeda baik secara perkataan, tindakan, mazhab dan pemikiran (Alwani,1987: 21). Beda pendapat baik secara lisan, pemikiran, mazhab, ide gagasan, cara berfikir dan bertindak merupakan potensi yang mendorong setiap orang untuk berfikir secara lebih kreatif dan situasional. Senada pula beda pendapat dalam pandangan Imam Subky ada tiga jenis yaitu beda pendapat secara pokok atau prinsipal, beda pendapat dari sisi aspek furu'iyyah (cabang) dan beda pendapat menyangkut perselisihan yang menyebabkan peperangan dan perpecahan. ${ }^{20}$ Sementara satu kata yang berhubungan dengan ikbtilaf adalah khilaf, berasal dari akar kata yang sama dan terkadang dipakai sebagai padanan kata dari ikhtilaf. Khilaf pada dasarnya adalah perbedaan, pertentangan atau bahkan perselisihan, lebih luas maknanya dan pengaruhnya dibandingkan konsep pertentangan itu sendiri secara langsung. Hal ini disebabkan dua hal tersebut senantiasa dianggap berbeda satu sama lainnya padahal dua hal itu, ide-ide ataupun orangorang yang tidak sepaham tidaklah selalu saling bertentangan atau berselisih paham. ${ }^{21}$ Bisa juga dianggap berbeda namun tidak mesti dianggap bertentangan atau berlawanan. Sedangkan Jadal secara terminologi merupakan bersikukuh untuk mempertahankan pendapat milikinya dan mencoba untuk berdiskusi dan berbantahan dengan tujuan untuk saling mengalahkan antara satu dengan yang lainnya. ${ }^{22}$ Ilmu jadal membuat cara berfikir untuk mencari banyak argumentasi yang bersumber dari al-Qur'an dan as-Sunnah atau sumber-sumber lain yang dijustifikasi hanya untuk memperkuat pendapatnya dengan tujuan mengalahkan lawan $^{23}$

Sementara Syiqaq sebuah diskusi yang menjadi keras dan kasar. Hal ini dilakukan hanya untuk menunjukkan keunggulan masing masing, nampak tertutup untuk tidak mau saling memahami dan menyetujui, tidak memperdulikan suatu kebenaran yang dilakukan hanya untuk memperoleh suatu kecongkaan dan keunggulan argumentasi dan pendapat. ${ }^{24}$ Syiqaq perlu dihindari agar tidak memberi kesan lebih unggul dan memilki super power yang

\footnotetext{
${ }^{20}$ Anwar Sadat, Ikbtilaf Di Kalangan Ulama Al-Mujtabidin, vol. 15, 2, 2015.

${ }^{21}$ Taha Jabir Fayyad Al-Alwani, Adab Al-Ikhtilaf Fi al-Islam.

${ }^{22}$ Taha Jabir Fayyad Al-Alwani, The Ethics of Disagreement in Islam, 1993.

${ }^{23}$ Taha Jabir Fayyad Al-Alwani, Adab Al-Ikbtilaf Fi al-Islam.

${ }^{24}$ Taha Jabir Fayyad Al-Alwani, The Ethics of Disagreement in Islam, 1993.
} 
paling tinggi dibanding yang lain. Hal ini sesuai dengan firman Allah dalam alQur'an (QS. An-Nisa': 35).

"Dan jika kamu kbawatirkan ada persengketaan antara keduanya, Maka kirimlah seorang hakam atau juru damai dari keluarga laki-laki dan seorang hakam dari keluarga perempuan. Jika kedua orang hakam itu bermaksud Mengadakan perbaikan, niscaya Allah memberi taufik kepada suami-isteri itu. Sesunggubnya Allab Maha mengetahui lagi Maba Mengenal'.

\section{b. Etika Beda Pendapat}

Dalam pergaulan sehari hari yang diawali dari bangun tidur hingga kemudian kembali tidur lagi, tanpa disadari interaksi antar sesama individu atau kelompok sering mewarnai kehidupan yang serba membutuhkan nilai komunikasi yang bersifat etis antar dua arah atau lebih. Namun komunikasi ini tentu tak luput dengan begitu lancar searah, akan tetapi mungkin banyak gesekan yang tak diterima, hal ini dipengaruhi oleh beragam kepentingan dan tujuan bahkan suasana hati yang tidak tenang pun ikut mempengaruhinya. Hal tersebut menjadikan komunikasi lebih didominasi oleh orang yang selalu mewujudkan kepentingan demi meraih suara yang terbanyak.

Sebelum terjadi sutau perbedaan pemikiran atau pendapat yang melahirkan perpecahan dan perselisihan antar sesama individu atau kelompok. Sedini mungkin untuk diminimalisir dari segi sikap (responsive), sikap yang melahirkan suatu tindakan positif dengan melihat unsur unsur kesamaan baik secara pemikiran, karakter atau tindakan yang tidak membuat orang lain merasa tersinggung dan terganggu. Kedua, persaudaraan antar muslim adalah hal yang sangat ditekankan oleh Rasulullah Saw, maka persaudaraan itu harus menjadi yang diutamakan dalam situasi apapun, termasuk dalam perbedaan yang berakibat berselisih. Ketiga, untuk hal-hal yang sifatnya fundamental atau prinsipal, seperti keimanan dasar, sama sekali tidak boleh ditolak atau diselisihi dengan alasan perbedaan, sebagai wujud menghargai keyakinan agama atau ideologi individu atau seorang. Keempat, biasakan berbagi pengetahuan dan saling menasehati tentang kebenaran dengan cara yang sabar dan lemah lembut sehingga mudah tercapai kesamaan pandangan visi dan tujuan. Sesuai dengan firman Allah dalam (QS. Al-Ashr:1-3). 
"Demi masa. Sesunggubnya manusia itu benar-benar dalam kerugian. kecuali orangorang yang beriman dan mengerjakan amal saleb dan nasehat menasehati supaya mentaati kebenaran dan nasehat menasehati supaya menetapi kesabaran."

Kelima, utamakan 'Itiba' mengikuti para ulama' (faqih/fuqaha') yang mendalam pengetahuannya dan Sholeh perilakunya sebagai rujukan dan tempat bertanya, agar memperoleh pencerahan berfikir secara jernih. Keenam, kritik dan peringatan dari sesama muslim anggaplah sebagai kepedulian dari saudara dan termasuk perilaku khayr (baik), oleh karena itu harus dilakukan dengan jalan yang baik dan diterima secara baik pula. ${ }^{25}$

Dalam hal menyikapi beda pendapat atau pemikiran dari pihak lain, baik sesama muslim atau non-Musliam, ada beberapa hal yang menjadi acuan alAlwani yakni setiap manusia yang dilahirkan di muka bumi ini dalam keadaan fitrah artinya manusia secara fitrahnya ber-Tuhan bertaubid. Manusia yang lahir memiliki Tuhan yang sama hingga disebut oleh al-Alwani kalimat at-Taubid (Satu Tuhan) dan taubid al-kalimah (Kekompakan). Saling menghargai dalam hal perbedaan tergolong taubid al-kalimah. Sementara semua orang memiliki Tuhan yang sama yaitu Allah termasuk kalimat at-Taubid. ${ }^{26}$ Kedua duanya sangat penting untuk dijadikan landasan dasar dalam berfikir guna memperoleh suatu pandangan yang universal tentang Tuhan.

Beda pendapat merupakan tanda tanda kreasi Tuhan dan sebuah indikasi tentang kekuatan sempurna-Nya. Apapun yang diciptakan oleh Tuhan telah ditahbiskan sebagai hal yang berbeda baik secara mental, bahasa, kulit, persepsi dan pemikirannya. ${ }^{27}$ Perbedaan apapun yang melanda umat manusia sudah terjadi sejak nenek moyang yang diawali sejak pra Islam dan setelah Islam merupakan bagian manifetasi Tuhan di alam yang beragam. Asalkan perbedaan pendapat tidak melebihi batas wajar dan tetap berada dalam norma etika dan perilaku standar, ini adalah fenomena yang bisa terbukti positif dan sangat bermanfaat. ${ }^{28}$

\footnotetext{
25 Taha Jabir Fayyad Al-Alwani, Adab Al-Ikbtilaf Fi al-Islam.

${ }^{26}$ Taha Jabir Fayyad Al-Alwani.

${ }^{27}$ Taha Jabir Fayyad Al-Alwani, The Ethics of Disagreement in Islam, 1993.

28 Taha Jabir Fayyad Al-Alwani, The Ethics of Disagreement in Islam, vol. 2 (USA: The International Institute of Islamic Thought, 1996).
} 


\section{c. Sebab Sebab Ikhtilaf}

Sebab-sebab yang mendorong orang Ikbtilaf atau berbeda pendapat beberapa yang telah diuraikan al-Alwani antara lain.

\section{1) Sunnatullah}

Perbedaan merupakan sutau karakter atau tabi'at alam dan kehidupan, segala yang Allah ciptakan di alam raya tidak ada satupun yang memiliki tabi'at yang sama sehingga beragam variasi unsur unsur kehidupan yang membentuk dan melingkupinya. Ada hewan, tumbuhan, makhluq hidup yang kesemuanya tersusun dari unsur tanah, api, air dan udara.

Karakter tabi'at manusia tergolong berbeda karena Tabi'at manusia yang diciptakan berbeda-beda dan memiliki kepribadian sifat, tabi'at, pemikiran sendiri-sendiri. Yang itu semua memiliki unsur kepribadian sendiri snediri.

Karakter tabi'at agama, adanya ayat-ayat mutasyabihat yang memang menuntut kita untuk berijtihad dan menggali makna makna yang paling hakiki dan fundamental yang terdapat pada kitab suci yang diwahyukan oleh Tuhan. Ayat ayat mutasyabibat memberikan peluang yang besar bagi mufassir dalam rangka memaknai teks al-Qur'an sesuai dengan semangat zaman.

Karakter tabi'at bahasa, adanya pemahaman yang berbeda, logat accent arti \& makna bahkan ekspresi dan budaya yang membentuk karakter yang berbeda. ${ }^{29}$ Bahkan di dalam al-Qur'an yang ditafsirkan semisal kaya 'Ayn bisa jadi memiliki makna organ penglihatan yakni mata, air yang mengalir dengn deras, emas murni dan seorang intel (mata mata) memiliki perbedaan makna dan para sarjana mujtahiudun kesulitan dalam memberikan makna secara baku.

\section{2) Karakter Ambivellen Manusia}

Dalam menghadapi perbedaan pendapat karakter manusia cenderung bersifat ambivalent (sikap yang bertentangan) di satu sisi mampu menerima kenyataan bahwa manusia itu berbeda-beda, namun disisi lain merasa tidak nyaman dengan adanya perbedaan, bahkan cenderung marasa terancam dengan adanya perbedaan-perbedaan itu. Sehingga lebih mengutamakan untuk menghindar dan tidak mau untuk melakukan intensi dialog bersama. simpulnya perbedaan sebagai fakta yang bersifat mutlak, dan kesamaan dan kebersamaan adalah sebuah kemungkinan harus diupayakan (al-Alwani,1996: 80). Karakter

${ }^{29}$ Taha Jabir Fayyad Al-Alwani. 
ambivellen manusia ini menjadi sebab tidak peduli dengan aktivitas untuk menjalin sebuah kerja sama dan saling terbuka.

\section{3) Karakter Agresif Manusia}

Melihat karakter manusia yang nampak agresif, sifat yang ingin unggul dan menguasai sesuai dengan perspektif psiko-analisa, manusia secara alamiah memiliki sifat agresif. Hal ini juga diisyaratkan oleh para Malaikat pada saat penobatan Adam (manusia) sebagai khalifah Allah, bahwa manusia punya karakter aggressor (senang menumpahkan darah).

Agresif disini dapat diartikan menyerang/menaklukan, dan secara implisit memiliki makna menguasai, memiliki dan menghancurkan (destruktive). Dalam perspektif filsafat eksistensialisme, agresif berkonotasi egosentik yakni diri sebagai pusat segala hal. Artinya segala hal yang menjadi tujuan manusia faktor penentu adalah kepentingan ego masing masing tanpa melihat dan mempertimbangkan kepentingan orang lain yang lebih utama.

Manusia seringkali hanya mencari dan memilih media untuk mengekspresikan kecenderungan agresi tersebut. Dengan kata lain, agresi bukanlah suatu reaksi seorang individu manusia terhadap stimulus (rangsangan) dari luar, melainkan rangsangan dalam yang sudah "terpasang" yang mencari pelampiasan dan akan terekspresikan melalui media rangsangan yang kecil sekalipun. Media itu kadang hanyalah sekedar pijakan dalam membangaun alasan untuk menjadikan ekpresi agresif itu menjadi sah secara sosial. Pelampiasan efek yang menimbulkan kesan agresif dan frontal membuat ketidakadilan dalam memilah suatu informasi yang bersumber dari media.

\section{4) Beda Pemikiran}

Beda pemikiran nampak pada karakter dalam mengambil sisi keputusan dan kebijakan yang terdapat dalam dirinya, hal ini karena dipengaruhi oleh persoalan cara metode dan pendekatan yang digunakan dalam melihat objek dan permasalahan yang bersumber dari informasi yang bertebaran di media atau buku buku instan tentang Agama.

Kedua, tentang aspek yang mendasari orang berbeda pendapat yaitu berkaitan dengan masalah kelebihan pengetahuan over pengetahuan yang menimbulkan sikap berfikir secara kritis yang melampaui batas. Hal apapun yang dianggap tidak cocok dengan cara berfikinna akan dikritisi secara mendalam yang berakibat pada sentimen dan kekacauan pandangan dan juga 
pada keterbatasan pengetahuan manusia yang tidak memberi ruang pada suatu sudut pandang baru manakala memiliki persoalan hidup yang membebaninya.

Ketiga, permasalahan yang sering kali memicu perbedaan pendapat secara fundamental adalah konteks masalah politik \& kepentingan. Kedua hal tersebut memberikan pengaruh dalam menentukan karakter pilihan politik, sebagaimana beberapa bulan lalu adanya hajatan besar dalam menentukan seorang pemimpin negara. Dari beragam pilihan yang berbeda memicu unsur kekurangan muatan pengetahuan hingga terkesan nampak tersingung jika pilihanya harus berbeda.

Keempat, permasalahan kesan efek yang diterima saat bergaul dengan sebagaian orang atau banyak orang dan hal itu muncul baik di media sosial atau secara langsung akan membuat penilaian yang berbeda. Penilaian yang berbeda ini rawan menimbulkan semacam pandangan yang tidak jernih dan adil.

\section{d. Akhlaq atau Perilaku}

Suka membangga-banggakan diri dan kagum terhadap pendapat sendiri. Jika bercerita dengan orang lain yang selalu disampaikan adalah diri sendiri, keunggulan diri dan kemampuan diri bisa melakukan apa saja tidak mau mendengar apa kata orang fokus pada pembicaraan yang dikatakan diri sendiri. Ini yang diunggulkan suatu bentuk prestasi yang benar benar mengagumkan.

Berburuk sangka dan mudah menuduh orang tanpa bukti yang valid. Biasanya kendala orang tidak mampu menilai dan memahami dengan baik akan memiliki dampak bahwa apa yang dinilai selalu terkesan timbul kontroversi (pro and kontra). Buruk sangka mengutamakan aspek emosi perasaan atau sensi dalam setiap memahami segala persoalan yang menimpa dirinya.

Faktor egois dan mengikuti hawa nafsu mengarah pada sentimen dan lebih mengutamakan kepentingan sepihak, baik untuk kepentingan personal atau kepentingan kelompok masyarakat umatnya. Sehingga akan berdampak pada tindakan regresif kemunduran perilaku yang jauh dari nilai norma dan kesopanan.

Pemahaman yang cenderung fanatik yang mendorong seorang beda pendapat, kepada pendapat orang tertentu dianggap tidak sejalan maka yang ada kesalahan demi kesalahan yang nampak pada penilaian dirinya. Fanatik di sini tentu tidak hanya pada pemahaman tentang pengetahuan, ilmu, budaya seni. Namun fanatik pada golongan aliran beragama jamaah atau suku daerah tertentu yang dinilai beda akan melahirkan karakteristik beda pendapat. 


\section{e. Manfaat Beda Pendapat Ikhtilaf}

Manfaat dalam menyikapi beda pendapat Ikhtilaf dipengaruhi oleh faktor untuk mencari pengetahuan dan kebenaran yang sesungguhnya. Ikhtilaf yang telah terjadi di kalangan umat terdahulu merupakan bagian dari kenyataan alamiyah hidup manusia dewasa ini. Oleh karena itu, untuk dapat memberikan manfaat bagi kehidupan umat, ikbtilaf harus memiliki ketentuan-ketentuan sebagai berikut: 1.) Jika niatnya jujur orang yang bersangkutan memiliki tanggung jawab bersama, tidak memilih bagian kepentinganya sendiri. 2.) Ikbtilaf baik itu digunakan untuk mengasah dan memperkuat otak dan membuka cakrawala berpikir. 3.) Memberikan kesempatan berbicara kepada lawan bicara dan bermuamalat dengan manusia lainnya sesuai dengan tingkat penghayatan, pemahaman dan pengalamannya dalam melihat realitas hidup di lingkungan sekitarnya. Sehingga membentuk suatu kehidupan yang selaras dengan dimensi alam dan manusia ${ }^{30}$

Dari ketentuan atau prasyarat tersebut, telah memberikan kegunaan dan manfaat yang bisa diambil pelajaran antara lain. Pertama, memberikan banyak pengetahuan tentang dalil yang bisa dijadikan dasar perilaku. Kedua, wahana untuk melatih daya nalar kritis, saling sumbang pemikiran membuka kesempatan yang luas untuk mengetahui berbagai konsep yang tidak mudah dijelajahi sendiri, namun lebih memperkaya perspektif yang diambil. Ketiga memunculkan banyak alternatif solusi bagi seseorang yang menghadapi sebuah fenomena tertentu. Solusi dalam memberikan sudut pandang yang kontekstual dan progresif. ${ }^{31}$

\section{f. Beda Pendapat Dalam Perwujudan Nalar Toleransi}

Persoalah persoalan dalam hidup yang terjadi seringkali tak terhindarkan dalam menjalin interaksi antar sesama manusia, terlebih komunikasi bersinggungan tidak hanya secara langsung, namun juga seringkali lewat jejaring atau media sosial. Hal ini yang memungkinkan setiap orang mengetahui karakternya masing masing, sehingga pandangan yang melahirkan gagasan dan ide yang berbeda mendorongnya untuk bersikap secara adil dalam diri sendiri atau orang lain. Sesuai dengan sejarahnya tentang asal usul beda pendapat, sejak

\footnotetext{
${ }^{30}$ Anwar Sadat, Ikbtilaf Di Kalangan Ulama Al-Mujtabidin.

${ }^{31}$ Taha Jabir Fayyad Al-Alwani, Adab Al-Ikbtilaf Fi al-Islam.
} 
diawali pada masa sahabat bahwa Allah menciptakan segala yang ada di dunia ini merupakan Sunnatullah artinya bekal yang Allah berikan kepada manusia berupa akal memiliki kemampuan dan kapasitas keilmuwan yang berbeda, ketajaman, analisis yang berbeda antara satu dengan yang lainya. Dengan demikian, secara alami perbedaan hasil pemahaman dan penafsiran terhadap Islam, al-Qur'an dan al-Sunnah, sudah terjadi di kalangan sahabat, baik di saat Rasulullah Saw masih hidup dan apalagi lagi setelah beliau wafat ${ }^{32}$

Perbedaan dikalangan para sahabat Nabi, ada beberapa etika yang bisa dipetik antara lain, pertama mereka tidak membuat atau mempermasalahkan persoalan persoalan kecil. Jika ada masalah masalah yang tampak bertentangan mereka lalu mengkonsultasikan kepada Nabi Muhammad Saw sebagai pembawa pencerahan. Kedua, jika terjadi perbedaan pendapat meskipun mereka berusaha menghindarinya, maka para sahabat berusaha dengan cepat merujuk ke al-Qur'an dan as-Sunnah. Ketiga, para sahabat bertindak dengan penuh komitment dan patuh terhadap aturan al-Qur'an dan Nabi. Keempat, Nabi biasanya menunjuk para sahabatnya jika ada hal yang benar dan salah terus menimbulkan pertanyaan kontroversi maka dibukalah sebuah dialog. Ini dilakukan agar saling percaya dalam menjamin setiap penilain satu sama lain. ${ }^{33}$

Lebih lanjut, Haidar Bagir menyatakan bahwa etika dalam beda pendapat disinggung dalam filsafat Islam bahwa memiliki ciri-ciri sebagai berikut: pertama, Islam berpihak pada teori tentang etika yang bersifat fitri. Artinya, semua manusia pada hakikatnya, baik itu Muslim ataupun bukan, memiliki pengetahuan fitri tentang baik dan buruk. Baik dan buruk ini merupakan ciri khas dalam menentukan piliha perilaku yang dijadikan sandaran dalam hidup. Kedua, moralitas dalam Islam didasarkan kepada keadilan, yakni menempatkan segala sesuatu pada porsinya. Artinya sikap kritis terhadap diri sendiri mendorongnya untuk senantiasa instropeksi diri, berefleksi sebagai wujud meletakkan keadilan diatas kepentingan masing masing. Tanpa merelatifkan etika itu sendiri, nilai suatu perbuatan diyakini bersifat relatif terhadap konteks. $^{34}$

Beda pendapat sejatinya mengarah pada ranah sikap menghargai pendapat dan pemikiran seorang yang berbeda. Baik beda pendapat dalam urusan ideologi, keyakinan, kulit, ras, suku, budaya, bahasa terlebih lagi urusan selera setiap insan antara yang satu dengan yang lainya secara spesifikasi

\footnotetext{
32 Jamrah, Suryan A, "Ikhtilaf Dan Etika Perbedaan Dalam Islam," Jurnal Toleransi, 2, 6 (2015).

33 Taha Jabir Fayyad Al-Alwani, Adab Al-Ikbtilaf Fi al-Islam.

${ }^{34}$ Magnis Suseno, Franz, Filsafat Sebagai Ilmu Kritis.
} 
sangatlah tidak sama. Sebagai manusia sudah seharusnya mengetahui dan menyadari lebih dalam lagi akar setiap persolan yang menimbulkan perpecahan mampu diminimalisir sedini mungkin. Meminimalisir setiap konflik yang menimbulkan perpecahan dibutuhkan suatu gagasan yang cemerlang dalam mencegah penyebab terjadinya perselisihan antar perbedaan baik berbeda dari segi pendapat, pemikiran, ide dan kepentingan. Dari gagasan dan ide tersebut guna menghasilkan konstruksi sikap yang lebih toleran dan menghargai dengan tidak memaksakan setiap pendapat mengharuskan sesuai dengan keinginan dan cara berfikir miliknya sendiri.

\section{g. Toleransi Sebagai Etika Ilmiah}

Beda pendapat yang melahirkan karakter yang lebih toleran, terbuka dan humanis biasanya ada aturan tertentu yang perlu dipahami. Pemahaman ini dalam rangka mengetahui aspek-aspek yang diperbolehkan dalam beda pendapat. Pertama beda pendapat saat memiliki bujjah atau dalil argumentasi yang valid dan kredibel, artinya sumber rujukan yang berasal dari al-Qur'an, hadis jelas dan nalar logika semakin menemui titik peran yang akurat sesuai dengan kaidah logika yang berlaku. Kedua, beda pendapat seharusnya tidak mengedepankan aspek kesensitifan hati yang mendorongnya berselisih dan terjadi celaan dan hinaan. ${ }^{35}$

Sedangkan beda pendapat yang tidak diperbolehkan dalam aturan bersosial kemasyarakatan ada beberapa antara lain. Pertama, beda pendapat lebih karena lantaran ada maksud disengaja menyelisihi/membangkang, mendebat dan bahkan mengungguli argumen atau bujjah orang lain, karena motif kedengkian, iri hati atau mengikuti hawa nafsu demi kesenangan yang mengakibatkan merasa paling unggul dan lebih superrior. Kedua, beda pendapat lantaran memiliki ideologi atau keyakinan yang dianggapnya paling final dan benar sendiri, yang kemudian menilai ideologi tafkiri sehingga akan mengakibatkan perpecahan dan permusuhan antar umat Islam baik sesama umat Islam atau umat agama lain. ${ }^{36}$

Dari beberapa aturan yang penulis ulas diatas tentu perlu penambahan dalam menjelaskan tentang toleransi. Toleransi merupakan ruh dan semangat akidah Islam yang tercermin dalam al-Qur'an sebagai wujud keniscayaan kehidupan sosial bagi seluruh umat manusia dan merupakan jalan bagi terciptanya kerukunan antar umat manusia dan umat beragama. ${ }^{37}$ Toleransi,

\footnotetext{
35 Taha Jabir Fayyad Al-Alwani, The Ethics of Disagreement in Islam, 1996.

${ }^{36}$ Taha Jabir Fayyad Al-Alwani.

${ }^{37}$ Muhammad Yasir, “Makna Toleransi Dalam Al-Qur'an,” Jurnal Ushuluddin, 2, XXII (2014).
} 
menjadi konstruksi wujud pemikiran dasar manusia dalam menyikapi segala macam aspek perbedaan, menemui peran yang krusial dalam memperkenalkan nilai-nilai etis yang mewujud dalam setiap perilaku individu masing masing.

Hal ini kentara setiap perilaku yang mendorong seseorang terbuka terhadap gejala perbedaan, tentu dipastikan pemahaman dan kesadaran seseorang mampu membentuk suatu pandangan yang lebih luas dan fleksibel dengan setiap arus globalisasi. Artinya setiap gejala berita dan informasi yang diperoleh tentu adanya alat filterisasi berupa bentuk proses kesadaran. Kesadaran merupakan dasar dari pengetahahuan manusia sehingga mampu mencapai level yang lebih tinggi manakala dijangkau dengan suatu tindakan action terus menerus dengan didorong oleh tujuan yang pasti dan berwujud dalam bentuk strong intention. ${ }^{38}$

Tingkat kesadaran seseorang ditentukan oleh beragam wawasan dan ilmu pengetahuan yang dimiliki terutama yang sudah terinternalisasi dalam kehidupan sehari hari. Dari kesadaran itu yang membentuk setiap kondisi invidu mampu menggunakan dan menyikapi setiap persoalan dengan lebih fleksibel dan kondisional. Kesadaran kesadaran tersebut antara lain.

Kesadaran magis merupakan sebuah kesadaran yang sangat diterministik. Artinya setiap persoalan yang menjerat langkah dan kehidupan setiap individu terkesan bahwa itu semua merupakan taqdir Tuhan. Percaya sepenuhnya tanpa ada daya untuk mempertanyakan ulang kepercayaan tersebut. Semisal ia harus hidup miskin, bodoh, terbelakang dan itu semua tergolong pasrah dari "suratan taqdir Tuhan" yang tidak bisa diganggu gugat. Ini termasuk cara berfikir abstrak dan metafisika sehingga tidak mampu berfikir secara bebas free will semakin tidak ada ruhnya ${ }^{39}$

Kesadaran naif sebuah kesadaran sedikit berada di atas tingkatanya dibanding dengan sebelumnya. Kesadaran naif ini merupakan kesadaran yang sudah masuk pada tahap lebih mengerti dan memahami namun kurang menganalisa persoalan persoalan sosial yang berkaitan dengan unsur unsur yang mendukung problem sosial tersebut. Semisal ia baru mengerti kalau dirinya itu tertindas, terbelakang, tersakiti dan hal itu semua tidak lazim. Hanya saja ini semua kurang mampu untuk memetakan secara sistematis persoalan persoalan untuk mendukung dalam memberi tawaran solusi dari problem

\footnotetext{
${ }^{38}$ Ayn Rand, Faith and Force: The Destroyers of the Modern World “in Philosophy, Who Needs It," n.d.

${ }^{39}$ Mansour Fakih, Mansour, et.al, Pendidikan Populer Membangun Kesadaran Kritis (Yogyakarta: Read Book, 2001).
} 
tersebut. Istilahnya tahu namun belum mampu untuk menyelesaikan dengan cara yang baik dan seksama.

Kesadaran kritis yakni jenis kesadaran paling ideal dibanding dua sebelumnya. Karena kesadaran ini bersifat analitis sekaligus praksis. Karena dengan kesadaran ini maka setiap orang mampu memahami setiap permasalahan hidup terutama dalam urusan konflik sosial dan beda pendapat. Dengan memetakan permasalahan pokok dan krusial yang kemudian dianalisis dan diidentifikasi unsur unsur melandasinya dengan jelas, maka solusi alternatif menjadi titik terang untuk ditinjau dan diselesaikan dengan melihat, memahami keterkaiatan antar ideologi dan struktur sosial sebagai akar masalah. Ini dilakukan karena setiap pemahaman yang melahirkan cara pendang yang berbeda mendorong orang gampang menjustifikasi atau menilai tanpa melihat unsur unsur yang meliputi di dalamnya, sehingga ini yang rawan konflik dan berselisih.

Kesadaran transformatif termasuk puncak dari kesadaran kritis. Setiap indvidu jika sudah masuk tahapan kesadaran transformatif tentu akan lebih lihai dalam mewujudkan nalar kritisnya menjadi suatu perubahan yang menjelma menjadi wujud praksis dalam kehidupan. Hal ini terbukti antara ide, perkataan dan tindakan serta progresifitas dalam posisi seimbang. Karena kesadaran transformatif ini yang kemudian menjadikan manusia benar-benar memilki derajat sebagai manusia yang unggul dan sempurna. Kesadaran transformatif yang dibutuhkan oleh setiap manusia telah mendorong cara berfikir out of the box atau beyond self consciousness. Landasan yang digunakan etika yang mewujud dalam perilaku dan tindakan seseorang semakin lebih eksis dan progres kearah yang lebih toleran setiap keadaan sosial yang mempengaruhinya.

\section{h. Analisis Kritis Etika Ilmiah}

\section{Pemikiran Etika Ilmiah Taha Jabir Alwani}

Permasalahan tentang etika merupakan acuan yang paling asasi dalam kepribadian setiap insan. Merujuk pada pentingnya beragam wawasan yang melahirkan pemikiran seorang mampu mendayagunakan akalnya sebagai tonggak dalam memilih dan memilah informasi dengan seksama dan cermat. Setiap informasi yang diperoleh akan membentuk kepribadian diri tunggal. Sehingga tak jarang aspek kepribadian ini yang melahirkan perilaku moral, moralitas yang mendorong kearah yang lebih baik, yang lebih transformatif sebagai wujud betapa pentingnya penguasaan atau menginternalisasi nilai nilai etika dalam kehidupan yang semakin komplek ini. Hal ini merupakan wadah 
untuk memilki nilai toleransi antar sesama umat manusia. wadah toleransi wujudnya menghargai setiap pendapat dan pemikiran yang beda.

Buku yang dibahas Taha Jabir al-Alwani yang diberi judul etika beda pendapat versi Inggris "The Ethics of Disagreement in Islam" versi arab adab alIkhtilaf fi al-Islami merupakan buku etika yang terjadi dikalangan ulama ahli hukum Fuqoha'. Namun sebetulnya banyak nilai nilai etika yang bisa dipetik pelajaranya sebagai bagian dari pengetahuan ilmiah berkaitan dengan etika khusus. Pengetahuan ilmiah yang berasal dari etika ini berupaya dalam rangka membangun sebuah tujuan satu 'ummah, tingkat level yang lebih tinggi menjunjung nilai kerukunan toleransi antar umat manusia.

Beda pendapat menjadi basis etika ilmiah dalam mewujudkan nalar toleransi. Pada perkembangan selanjutnya di masa Islam awal telah dijelaskan oleh Al-Alwani dalam bukunya sebagai berikut. Ada beberapa hal yang perlu disampaikan.

\section{Menghindari Kebencian}

"The early Muslims did have disagreements. But theirs were differences of opinion and not reasons for estrangement and schism. They differed but they did not separate. This was because the unity of hearts and of objectives was far more important to them than selfish considerations. They managed to rid themselves of personal weaknesses and were keen to recognize and correct any lapses they committed. The Prophet, peace be on him, once told his companions about a man who was among the best of them and about the good news that he was of those destined for paradise. They examined the person's attitudes and conduct to under stand the reason for his supreme achievement. The Prophet eventually told them that the person's achievement was due to the fact that he never went to sleep while there was a trace of rancor in his heart against any Muslim. The source of the calamity which afflicts us today is within us, in our hearts. Our tendencies towards isolationism are merely an expression of self-betrayal. In external aspects, we might not differ much from others. God says: "Keep away from all sin, open and secret" (6: 120)."

"Umat Islam awal mula memang memiliki perbedaan pendapat. Namun saat mereka berbeda pendapat bukan bermaksud untuk memisahkan dan perpecahan. Mereka berbeda tetapi tidak berpisah. Ini karena kesatuan hati dan tujuan jauh lebih penting baginya daripada kepentingan egois. Mereka berhasil melepaskan diri dari kelemahan pribadi dan ingin 
mengenali dan memperbaiki kesalahan yang mereka lakukan. Nabi Muhammad Saw baginya, pernah memberi tahu para sahabatnya tentang seorang lelaki yang termasuk yang terbaik di antara mereka dan tentang kabar baik bahwa ia adalah dari mereka yang ditakdirkan untuk surga. Mereka menguji sikap dan perilaku orang tersebut untuk memahami alasan pencapaianya yang tertinggi. Nabi akhirnya memberi tahu mereka bahwa pencapaian orang tersebut disebabkan oleh fakta. Bahwa orang tersbut tidak pernah tidur duluan ketika ada jejak rasa dendam yang menyelimuti hatinya terhadap sesama muslim. Sumber bencana yang menimpa kita hari ini adalah dalam diri kita, di dalam hati kita. Kecenderungan kita terhadap isolasionisme (menjahui) hanyalah ekspresi pengkhiantan diri. Dalam aspek eksternal, kita mungkin tidak jauh berbeda dari yang lain. Allah berkata berkata "dan tinggalkanlah dosa yang nampak dan yang tersembunyi". ${ }^{40}$

Sejarah mencatat bahwa beda pendapat yang tujuannya tidak untuk memisahkan atau memperselisihkan masalah. karena semua orang menginginkan persatuan dan kesatuan antar ummat. Keinginan bersatu itu telah banyak menghapuskan rekam jejak yang tidak baik. Beda pendapat yang membawa kemaslahatan umat lahir dari akal sehat seorang yang digunakan untuk melawan keinginan atau hawa nafsu yang berprioritas pada kepentingan personal. Adapun hal hal yang paling pokok dalam menyikapi perbedaan pendapat menghindari rasa benci terhadap sesama umat muslim. Karena kebencian yang merasuki hati seorang menjauhkan diri dari kebahagiaan atau ketenangan batin. ${ }^{41}$

\section{Mengindari Perselisihan dan Permusuhan}

"If differences of opinion operate in a bealthy framework they could enrich the Muslim mind and stimulate intellectual development. They could help to expand perspectives and make us look at problems and issues in their wider and deeper ramifications, and with greater precision and thoroughness. Sadly, with the waning of the Ummah, this is not the case. All of the positive advantages that can stem from bealtby differences have given way to the chronic disease and deadly poison of discord which is weakening and eroding our spirits and putting us on a self-destruct course. The situation has reached such a state that some of those who hold divergent positions actually engage in physical annibilation while others take to regarding the enemies of Islam as closer to them than

\footnotetext{
40 Taha Jabir Fayyad Al-Alwani, The Ethics of Disagreement in Islam, 1996.

${ }^{41}$ Henry Manampiring, Filosofi Teras Filsafat Yunani-Romawi Kuno Untuk Mental Tanggub Masa Kini (Jakarta: Kompas, 2019).
} 
their fellow Muslims who share the same basic beliefs. Recent and earlier Muslim history bas witnessed many sad and painful scenes when the vast energies and resources of the Ummah have fed and continue to feed the flames of discord, strife, and civil war which only seem to increase in intensity with each passing day."

"Jika beda pendapat berperan dalam kinerja yang sehat, maka mereka dapat memperkaya daya pikiran setiap muslim dan menumbuh kembangkan daya intelektual. Mereka dapat membantu memperluas sudut pandang perpektif dan membuat kita melihat permasalahan permasalahan konteks yang lebih luas dan dalam dan juga dengan beragam ketelitian yang lebih besar. Sayangnya, dengan semakin memudarnya umat, ini bukan masalahnya. Semua pengaruh positif sumbernya dari perbedaan secara sehat namun ada jalan yang telah diberikan kepada penyakit kronis dan racun mematikan berupa pertikaian yang melemahkan dan mengikis semangat kita dan menempatkan kita pada jalur penghancuran diri. Situasi ini telah mencapai kondisi sedemikian rupa sehingga beberapa dari mereka yang memegang posisi berbeda, sebenarnya terlibat dalam pemusnahan fisik sementara yang lain menganggap musuh-musuh Islam lebih dekat dengan mereka daripada sesama Muslim mereka yang memiliki kepercayaan dasar yang sama. Sejarah Muslim baru-baru ini dan sebelumnya telah menyaksikan banyak adegan sedih dan menyakitkan ketika energi dan sumber daya yang luas dari umat telah memberi makan dan terus memberi makan api perselisihan, perselisihan, dan perang saudara yang tampaknya semakin meningkat intensitasnya setiap hari". ${ }^{2}$

Perselisihan pada dasarnya harus dihindari karena menyangkut hubungan buruk di antara kedua belah pihak. Karena menilisik dari penjelasan al-Alwani bahwa penyakit fisik (kronis) ditimbulkan dari rasa hati yang tidak bisa menerima pikiran beda, akhirnya timbul rasa stress tekanan jiwa yang tak kunjung usai diobati. Tidak hanya itu beda pendapat juga mendorong seorang untuk bertindak lebih ekstrem, dengan cara bertindak untuk memusudi selama lamanya, karakter semacam ini yang perlu dihindari lebih dini.

\section{Manusia itu sebagai umat yang Sama}

"Since the Muslims have pure faith in and worship God alone, since their Prophet, their scripture, the direction they turn in salaab3 and the acknowledged reason for their existence are all one and the same, it must follow that they should be united in a common endeavor: "This, your community," says God in the Qur'an, "is a single

${ }^{42}$ Taha Jabir Fayyad Al-Alwani, The Ethics of Disagreement in Islam, 1996. 
community and I am your Lord and Sustainer; therefore worship Me" (21: 92). In spite of this, Muslims have unfortunately forsaken the uncompromising belief in and worship of God alone and abandoned the call to join forces with one another."

"Karena kaum Muslim memiliki keyakinan murni ikblas dan hanya menyembah Tuhan saja, karena Nabi mereka, kitab suci mereka, arah yang mereka berikan dalam sholat dan alasan yang diakui untuk keberadaan mereka semuanya satu dan sama, maka harus disimpulkan bahwa mereka harus dipersatukan dalam satu persamaan. ikhtiar: "Ini, komunitasmu," kata Allah dalam Al-Qur'an, "Sesungguhnya (agama Tauhid) ini adalah agama kamu semua; agama yang satu -artinya sama dalam pokok-pokok kepercayaan dan pokok-pokok Syari'at- dan aku adalah Tuhanmu, Maka sembahlah aku." (21: 92). Walaupun demikian umat Islam sayangnya telah meninggalkan kepercayaan yang tak kenal kompromi dan hanya menyembah Allah dan mengabaikan seruan untuk bergabung dengan satu sama lain". ${ }^{43}$

Saat umat muslim masuk kategori bingkai sebagai manusia dan memiliki Tuhan yang sama dan semua orang mengakui keberadaan Tuhan, sama sama menjalankan syaria'at. Hal ini yang menjadi landasan untuk senantiasa hidup secara rukun, toleran, saling memahami. Selama Tuhannya Allah semua manusia itu sama, terlebih dalam hubungannya secara sosial.

\section{Mengembalikan Dimensi Keimanan}

"We need to be fully conscious of the dangers of this situation and make sincere attempts to deal with the roots of the crisis of Muslim disunity. To begin with, we need to restore "the dimension of faith" in the hearts of Muslims. This dimension has almost ceased to be the primary factor in regulating Muslim relationships. This is the result of a distorted understanding of Islam, harmful practices, and the pressures and impositions of non-Islamic societies. The restoration of the faith dimension and a sound understanding of Islam are the only true guarantees for rectifying our relationships, getting rid of our differences, and removing all traces of rancor from our bearts. How comforting and bow delightful this would be! A sound knowledge and understanding of Islam would give us a proper appreciation of the various categories of actions: what is recommended or permissible, what is compulsory or obligatory, and so on. We would be able to keep before us the higher objectives of our striving and be wary of constant jostling with one another via argumentation and discord. We have undoubtedly lost the ethics and norms of proper Islamic behavior and the proper regard

${ }^{43}$ Taha Jabir Fayyad Al-Alwani, The Ethics of Disagreement in Islam, 1993. 
for moral imperatives and have thus fallen an easy prey to internal disintegration and internecine strife. This is the legacy of what the Qur' an calls "a narrow and constricted existence" and a life of failure. We have ended up in impotence and ruin. Such indeed was the warning of God: "And do not dispute with one another lest you fail and your moral strength desert you" (8: 46)."

"Kita harus sadar sepenuhnya akan bahaya situasi ini dan melakukan upaya ikhlas yang berhubungan dengan akar krisis perpecahan umat Islam. Untuk memulainya, kita perlu mengembalikan "dimensi iman" di hati umat Islam. Dimensi ini hampir tidak lagi menjadi faktor utama dalam mengatur hubungan Muslim. Ini adalah hasil dari pemahaman yang keliru tentang Islam, praktik-praktik berbahaya, dan tekanan serta pemaksaan masyarakat non-Islam. Pemulihan dimensi keimanan dan pemahaman Islam yang kuat adalah satu-satunya jaminan pokok untuk memperbaiki hubungan kita, menyingkirkan perbedaan-perbedaan kita, dan menghilangkan semua rekam jejak dendam dari hati kita. Betapa menggembirakan dan menyenangkan ini! Pengetahuan dan pemahaman Islam yang baik akan memberi kita apresiasi yang layak atas berbagai kategori tindakan: apa yang direkomendasikan atau diizinkan, apa yang diwajibkan dan sebagainya. Kita akan dapat menjaga di hadapan kita tujuan-tujuan yang lebih tinggi dari perjuangan kita dan waspada terhadap saling berdesak-desakan satu sama lain melalui argumentasi dan perselisihan. Kita tidak diragukan lagi telah kehilangan etika dan normanorma perilaku Islami yang tepat dan penghormatan yang tepat terhadap keharusan moral dan karenanya telah menjadi mangsa yang mudah bagi disintegrasi internal dan perselisihan internal. Ini adalah warisan dari apa yang disebut Al-Qur'an sebagai "eksistensi yang sempit dan terbatas" dan kehidupan yang gagal. Kita berakhir pada impotensi dan kehancuran. Sesungguhnya demikianlah peringatan Allah: "Dan taatlah kepada Allah dan Rasul-Nya dan janganlah kamu berbantah-bantahan, yang menyebabkan kamu menjadi gentar dan hilang kekuatanmu dan bersabarlah. Sesungguhnya Allah beserta orang-orang yang sabar (8: 46). ${ }^{44}$

Pokok dimensi keimanan dari Al-Alwani menjadi skala prioritas dalam memperbaiki hubungan antar sesama manusia. Namun iman yang seperi apa, yang mampu menginternalisasi sebuah perbuatan yang baik. Dalam surat QS.

${ }^{44}$ Taha Jabir Fayyad Al-Alwani. 
Al-Ashr:1-3. Secara tafsir sufi al-Tustari menjelaskan bahwa keimanan seorang muslim bisa tercapai dengan kuat, jika pertama dilakukan bertindak dalam tahapan sabar, tidak ada pahala yang lebih besar dari sabar. Sabar ada 4 macam yang akan melahirkan keimanan. Pertama, sabar dalam menjalankan taat kepada Allah. Kedua, sabar menjahui segala yang berhubungan dengan maksiat. Ketiga, sabar terhadap musibah yang menimpa, baik musibah berupa bencana alam, atau bencana perselisihan. Dan keempat, sabar terhadap perbuatan dan tingkah laku sesama makhluq. Artinya kegiatan sosial yang berhubungan dengan semua mahkluq hidup tidak ada upaya untuk bertentangan dengannya. ${ }^{45}$

\section{Meningkatkan Wawasan tentang Perbedaan Pendapat}

"Often people are unable to look at matters in a balanced, bolistic way and see the various dimensions of an issue. Their narrow perspectives only allow them to see a minor aspect which is then inflated and blown up out of all proportion and given an importance to the exclusion of any other aspect or issue. This minor aspect is constantly commented upon and promoted. It becomes the basis for judging, disdaining, or accepting others. To strengthen this aspect, help from the enemies of the religion might even be sought against other Muslims who bappen to have a divergent view."

"Seringkali orang-orang tidak dapat melihat hal-hal secara seimbang, menyeluruh bolistik dan melihat berbagai dimensi masalah. Perspektif mereka yang sempit hanya memungkinkan mereka untuk melihat aspek kecil yang kemudian meningkat dan meledak keluar dari semua proporsi dan diberi arti penting dengan mengesampingkan aspek atau masalah lain. Aspek minor ini terus-menerus dikomentari dan dipromosikan. Itu menjadi dasar untuk menilai, meremehkan, atau menerima orang lain. Untuk memperkuat aspek ini, pertolongan yang memusuhi agama bahkan mungkin dicari Muslim lain yang kebetulan memiliki pandangan yang berbeda."

Meningkatkan dan memperluas wawasan ilmu pengetahuan menjadi hal yang paling fundamental dalam menyikapi setiap macam perbedaan pendapat, pemikiran dan ideologi. Memperluas wawasan menjadi ciri khas bahwa manusia itu makhluq yang dinamis sebagaimana yang digagas oleh Prof Musa Asy'rie tentang konsep manusia multidimensional. Artinya manusia bukan makhluq satu dimensi, karena permasalahan hidup manusia pada hakikatnya bersifat multidimensional, yang tidak bisa dipecahkan hanya dengan menggunakan pendekatan tunggal keimuwan ataupu pemikiran yang parsial. Berfikir secara multidimensionl ini yang mendorong orang mampu untuk senantiasa menyadari dimensi alam, kebudayaan dan dimensi Ilahi. Ketiga

${ }^{45}$ Ibn. 'Abd Allāh al-Tustarī, Tafsìr Al-Tustarì (Lebanon: Dar Khotob al-Ilmiyah, 2007). 
tiganya memberi pengetahuan yang pokok dalam mengetahui unsur unsur perilaku sesama muslim baik dan buruknya ${ }^{46}$

\section{Simpulan}

Melalui penelitian ini dapat disimpulkan bahwa:

Etika ilmiah yang bersumber dari karya Taha Jabir al-Alwani yang judulnya etika beda pendapat versi Inggris "The Ethics of Disagreement in Islam", telah memberikan ruang tersendiri dalam mencapai kemaslahatan antar umat Islam. Pada dasarnya awal mula pembahasan ini dalam rangka memberi wawasan terkait issu politik yang saling bertentang di dunia Islam. Pertentangan pertentangan diakibatkan oleh gejala gejala pemikiran, gagasan dan ideologi yang berbeda. Sehingga pedoman dan aturan moralitas menjadi tumpuan yang kuat dalam memberikan suatu pandangan yang lebih ilmiah dan komplek.

Etika ilmiah memberikan suatu cara pandang yang lebih holistik dalam mewujudkan suatu nalar dan ideologi yang lebih terbuka dan toleran. Hal ini disebabkan oleh sebuah kesadaran yang mencapai level yang lebih tinggi. Sehingga perlu penulis kuatkan dalam memberikan sebuah kesimpulan bahwa hasil yang diperoleh dari hasil kajian menelaah etika ilmiah al-Alwani mencakup (1). Kesadaran diri berupa magis, naif, kritis dan Transformatif. Kesadaran tersebut tergolong memiliki level pemikiran yang mendasar, kesadaran magis hanya menerima apa adanya yang sudah ditaqdirkan oleh Tuhan, kesadaran naif sadar dan mengerti tapi tak mampu menganalisa setiap permasalahan, kesadaran kritis yaitu mampu berfikir kritis dan analitis. Sedangkan kesadaran transformatif sebuah kesadaran yang mampu menjelma secara praksis dari hasil refleksi atas norma etika.

(2). Kesadaran sosial berupa saling menghargai, memahami, memaklumi setiap hal yang dianggap berbeda. Tidak mempermasalahkan yang sifatnya tidak penting dan tak berguna. Mencoba terbuka dengan segala kemungkinan kemungkinan yang terjadi.

(3). Kesadaran Revolusioner merupakan kesadaran yang menginginkan perubahan secara mendasar dan menyeluruh dari setiap aspek sendi sendi kehidupan manusia. Sendi sendi kehidupan manusia mengarahkan pada hubungan dan interaksi sosial antar umat Islam maupun yang lain.

(4).Kesadaran Ilahiah berupa betapa pentingnya menghindari perbuatan permusuhan, perselisihan, percekcokan, pemutusan hubungan kerabat yang dilarang oleh Allah Swt. Ini yang berakibat fatal hingga kemudian banyak

${ }^{46}$ Zaprulkhan, Paradigma Berfikir Multidimensional Perpektif Musa Asy'arie (Yogyakarta, 2019). 
bencana alam yang melanda disebabkan masyarakat Islam selalu bergesekan dan mencedarai antar umat Islam yang lain.

\section{Daftar Pustaka}

A Partanto Pius. Kamus Ilmiah Populer. Surabaya: Arkaloka, 1994.

Achmad Mudlor. Etika Dalam Islam. Surabaya: Al-Ikhlas, 1988.

Ahmad Amin. Ethika Ilmu Akblaq. Jakarta: PT Bulan Bintang, 1988.

Ahmad Charis Zubair. Kuliah Etika. Jakarta: Rajawali Press, 1967.

Alwani Zainab. Muraja'at Fi Tatawnur al-Manbaj al-Maqashidiy Inda alMu'Asbirin. al-Ma'had al-'Alamiy li al-Fikr al-Islami, n.d.

Anwar Sadat. Ikhtilaf Di Kalangan Ulama Al-Mujtahidin. Vol. 15. 2, 2015.

Ayn Rand. Faith and Force: The Destroyers of the Modern World "in Philosophy, Who Needs It," n.d.

Haidir Putra Daulay. Endidikan Islam Dalam Sistem Pendidikan Nasional Di Indonesia. Jakarta: Kencana, 2012.

Henry Manampiring. Filosofi Teras Filsafat Yunani-Romawi Kuno Untuk Mental Tangguh Masa Kini. Jakarta: Kompas, 2019.

Ibn. 'Abd Allāh al-Tustarī. Tafsìr Al-Tustarì. Lebanon: Dar Khotob al-Ilmiyah, 2007.

Jamrah, Suryan A. "Ikhtilaf Dan Etika Perbedaan Dalam Islam." Jurnal Toleransi, 2, 6 (2015).

K. Bertens. Etika. Jakarta: Gramedia, 2006.

Magnis Suseno, Franz. Filsafat Sebagai Ilmu Kritis. Yogyakarta: Kanisius, 1992.

- Kuasa Dan Moral. Jakarta: Gramedia, 1988.

Mansour Fakih, Mansour, et.al. Pendidikan Populer Membangun Kesadaran Kritis. Yogyakarta: Read Book, 2001.

Muhammad Yasir. "Makna Toleransi Dalam Al-Qur'an.” Jurnal Ushuluddin, 2, XXII (2014).

Sudarsono. Ilmu Filsafat. 2nd ed. Jakarta: Rineka Cipta, 2008.

Taha Jabir Fayyad Al-Alwani. Adab Al-Ikbtilaf Fi al-Islam. USA: Islamic Thought, 1987.

- The Ethics of Disagreement in Islam. Vol. 1. USA: Herndon, 1993.

- The Ethics of Disagreement in Islam. Vol. 2. USA: The International Institute of Islamic Thought, 1996.

W Poespoprodjo. Filsafat Moral; Kesusilaan Dalam Teori Dan Praktek. Bandung: Pustaka Grafika, 1999. 
Zaprulkhan. Paradigma Berfikir Multidimensional Perpektif Musa Asy'arie. Yogyakarta, 2019. 